\title{
HUBUNGAN ANTARA PERSEPSI TENTANG MANFAAT SEKOLAH DENGAN MINAT BELAJAR PADA SISWA KELAS X SMK ABDI NEGARA BINJAI TAHUN AJARAN 2018/2019
}

\author{
Dita Permana Sembiring ${ }^{1}$ Nurul Hasanah, M.Si , ${ }^{2}$ Surya Wibawa, SH , MH \\ Program Studi Bimbingan dan Konseling \\ STKIP Budidaya Binjai
}

\begin{abstract}
Abstrak
Persepsi siswa terhadap manfaat sekolah dipengaruhi oleh pengalaman, lingkungan, kebudayaan dan pola pikir. Pada setiap peserta didik diharapkan memiliki minat untuk belajar. Tetapi ada beberapa alasan peserta didik kurang minat dalam hal belajar, salah satunya peserta didik belum menyadari pentingnya manfaat sekolah untuk masa depan mereka, sehingga mereka kurang termotivasi untuk berlomba - lomba mencapai prestasi. Minat belajar adalah kecenderungan hati yang tinggi untuk belajar. Mendapatkan informasi, pengetahuan, kecakapan, melalui usaha, pengajaran, atau pengalaman. Penelitian ini bertujuan untuk mengetahui hubungan antara persepsi manfaat sekolah dengan minat belajar pada siswa kelas X SMK Abdi Negara Binjai Tahun Ajaran 2018/2019. Metode penelitian yang digunakan dalam penelitian ini merupakan jenis penelitian kuantitatif dengan metode korelasional. Terbukti dilihat nilai variabel persepsi manfaat sekolah terdistribusi secara normal dengan nilai $\mathrm{p}>0,05(0,230>0,05)$. Dan berdasarkan tabel diatas dapat dilihat nilai variabel minat belajar terdistribusi secara normal dengan nilai $\mathrm{P}>0,05(0,649>0,05)$. Berdasarkan hasil penelitian yang telah dilakukan, maka dapat disimpulkan bahwa ada hubungan yang sangat signifikan antara persepsi manfaat sekolah dengan minat belajar, hal ini dibuktikan dengan nilai hasil koefisien korelasi yang menunjukan angka 0,307 dengan nilai sig 0,016 dimana $r$ tabel $<0,05$. Artinya semakin tinggi persepsi manfaat sekolah, maka semakin baik minat belajar siswa tersebut. Sebaliknya, semakin rendah persepsi manfaat sekolah, maka minat belajar siswa semakin rendah.
\end{abstract}

Kata Kunci : Persepsi Manfaat Sekolah, Minat Belajar

\section{PENDAHULUAN}

- Latar Belakang Masalah

Pendidikan adalah sebuah proses untuk mengubah jati diri seorang peserta didik untuk lebih maju. Menurut para ahli, ada beberapa pengertian yang mengupas tentang defenisi dari pendidikan itu sendiri diantaranya menurut John Dewey, Pendidikan adalah merupakan salah satu Proses Pembaharuan makna pengalaman. Sedangkan Menurut H. Horne, Pendidikan merupakan proses yang terjadi secara terus menerus (Abadi) dari penyesuaian yang lebih tinggi bagi mahkluk manusia yang telah berkembang secara fisik dan mental, 
yang bebas dan sadar kepada Tuhan, seperti termanifestasi dalam alam sekitar, Intelektual, emosional, dan kemanusiaan dari manusia.

Belajar telah dimulai dari dalam kadungan hingga akhir hayat. Belajar merupakan suatu proses yang ditandai dengan adanya perubahan pada diri seseorang.perubahan sebagai hasil proses belajar dapat ditunjukkan dalam berbagai bentuk seperti berubah pengetahuannya, pemahamannya, sikap dan tingkah lakuya, keterampilanya, kecakapan dan kemampuannya, daya reaksinya, daya penerimaanya, dan aspek yang aspek yang terdapat pada individu. Oleh karena itu, satu hal yang harus peserta didik lakukan adalah Belajar.

Berkaitan dengan hal diatas, maka setiap peserta didik diharapkan memiliki minat untuk belajar. Hurlock mengatakan "Minat merupakan sumber motivasi yang mendorong orang untuk melakukan apa yang mereka inginkan bila mereka bebas memilih". Selanjutnya Slameto mengemukakan "Belajar adalah suatu proses usaha yang dilakukan individu untuk memperoleh suatu perubahan tingkah laku yang baru secara keseluruhan, sebagai hasil pengalaman individu itu sendiri di dalam interaksi dengan lingkungannya.

Minat belajar siswa adalah kesadaran dalam diri seorang siswa yang merasa ketertarikan pada mata pelajaran tertentu. Ketertarikan ini yang mendorong siswa untuk lebih berfokus terhadap mata pelajaran tersebut. Adanya minat yang besar dari siswa dapat menyebabkan siswa dapat belajar dengan sepenuh hati tanpa adanya paksaan. Dalam hal ini peserta didik diharapkan memiliki minat dalam belajar, sehingga dapat menyerap ilmu dan pendidikan yang diterima dari sekolah dimana ia belajar.

Menurut Ula "minat sangat berpengaruh terhadap proses dan hasil belajar. Jika bahan yang dipelajari tidak sesuai dengan minat seseorang, tentunya ia tidak akan bersemangat dalam belajar". Hal ini akan membawa pengaruh negatif terhadap hasil belajarnya. Berbeda halnya dengan seseorang yang belajar tentang bahan pelajaran yang sesuai dengan minatnya. Tentu saja ia akan bersemangat dalam proses belajar mengajar sehingga akan membawa pengaruh positif bagi hasil belajarnya kemudian. Demikian pula menurut Susanto bahwa "faktor minat merupakan faktor yang berpengaruh secara signifikan terhadap keberhasilan belajar siswa.

Berkaitan dengan hal diatas ada beberapa alasan peserta didik kurang minat dalam hal belajar, salah satunya peserta didik Belum menyadari pentingnya manfaat sekolah untuk masa depan mereka, sehingga mereka kurang termotivasi untuk berlomba-lomba mencapai prestasi. Rasa malas yang timbul dalam diri anak dapat disebabkan karena tidak adanya motivasi diri. Motivasi ini kemungkinan belum tumbuh dikarenakan anak belum mengetahui manfaat dari belajar atau manfaat dari sekolah. Tidak adanya minat seorang peserta didik terhadap suatu pelajaran akan timbuk kesulitan belajar. Belajar yang tidak ada minatnya mungkin tidak sesuai dengan bakatnya, kebutuhan, kecakapan, dengan tipe-tipe khusus anak banyak menimbulkan problema pada diri peserta didik.

Walgito mengemukakan persepsi adalah suatu proses yang didahului oleh pengindraan, yaitu merupakan proses yang 
berwujud diterimanya stimulus oleh individu melalui alat indera atau juga disebut proses sensoris.

Pentingnya persepsi adalah, pertama mengetahui semakin baiknya suatu objek, orang, pristiwa atau hubungan yang diketahui, sehingga dalam hal tersebut dapat diingat. Kedua dalam pengajaran, agar menghindari salah pengertian yang mengakibatkan peserta didik belajar sesuatu yang keliru atau yang tidak relevan. Ketiga memperbaiki kekeliruan terhadap sesuatu yang diajarkan baik melalui gambar atau potret yang menyerupai suatu benda yang sedang diajarkan.

Persepsi tentang sekolah pada siswa adalah suatu penapsiran siswa terhadap suatu stimulus, yaitu sekolah mereka. Persepsi siswa terhadap sekolah dipengaruhi oleh pengalaman, lingkungan, kebudayaan, dan pola pikir. Hal ini juga berlaku pada persepsi siswa terhadap sekolah.

Persepsi siswa terhadap manfaat sekolah dipengaruhi oleh pengalaman, lingkungan, kebudayaan dan pola pikir. Pada setiap peserta didik diharapkan memiliki minat untuk belajar. Tetapi ada beberapa alasan peserta didik kurang minat dalam hal belajar, salah satunya peserta didik belum menyadari pentingnya manfaat sekolah untuk masa depan mereka, sehingga mereka kurang termotivasi untuk berlomba - lomba mencapai prestasi. Menurut dari salah seorang guru di sekolah SMK Abdi Negara terdapat beberapa siswa yang memiliki kurangnya minat belajar, karena siswa tersebut belum mengetahui seluruhnya dari manfaat sekolah.

\section{- Identifikasi Masalah}

Masih banyak peserta didik kurang minat dalam hal belajar, salah satunya peserta didik Belum menyadari pentingnya manfaat sekolah untuk masa depan mereka, sehingga mereka kurang termotivasi untuk berlomba-lomba mencapai prestasi. Rasa malas yang timbul dalam diri anak dapat disebabkan karena tidak adanya motivasi diri.

Tidak adanya minat seorang peserta didik terhadap suatu pelajaran akan timbul kesulitan belajar. Menurut dari salah seorang guru di sekolah SMK Abdi Negara terdapat beberapa siswa yang memiliki kurangnya minat belajar, karena siswa tersebut belum mengetahui seluruhnya dari manfaat sekolah. Maka melalui penelitian ini peneliti ingin mengetahui apakah ada hubungan persepsi tentang manfaat sekolah mempengaruhi minat belajar pada siswa.

\section{METODE PENELITIAN}

Penelitian ini dilaksanakan di SMK Abdi Negara binjai yang beralamat di Jalan TA-Hamza, No. 689 Jatikarya, Binjai Utara, Kota Binjai, Sumatera utara. Jenis penelitian yang digunakan adalah kuantitatif korelasional. Penelitian ini bertujuan untuk menyelidiki sejauh mana variasi pada satu variabel berkaitan dengan variasi pada satu atau lebih variabel lain berdasarkan koefisien korelasi.

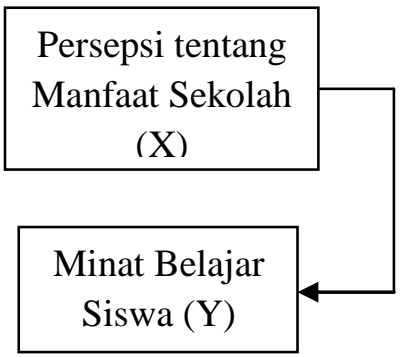

Gambar 1 : Desain Penelitian 
Populasi penelitian ini adalah siswa SMK Abdi Negara kelas $\mathrm{X}$ yang berjumlah 246 Siswa. Pengambilan sampel dilakukan dengan teknik simple random sampling (Pengambilan anggota sampel dari populasi dilakukan secara acak/ homogen).

Sampel dalam penelitian ini adalah siswa dari SMK Abdi Negara 6 orang dari kelas X TKR-1, 6 orang dari kelas X TKR2, 4 orang dari kelas $X$ ARSITEK, 7 orang dari kelas X TSM-1, 7 orang dari kelas $\mathrm{X}$ TSM-2 , 10 orang dari kelas $\mathrm{X}$ AP, 12 orang dari kelas $X$ TKJ, sehingga keseluruhan sampel berjumlah 49 siswa. Instrumen penelitian yang digunakan dalam penelitian ini yaitu angket bentuk skala dengan jenis skala Likert.

Analisis ini dengan cara mengkolerasikan masing-masing skor item dengan skor total. Dari hasil uji validitas skala persepsi manfaat sekolah dari 40 skala yang uji terdapat 10 yang tidak valid artinya $\mathrm{P}<0,25$, sedangkan skala minat belajar dari 40 item yang diujikan terdapat 12 item yang tidak valid.

\section{- Teknik Pengumpulan Data}

Untuk mengumpulkan data yang diperoleh dalam penelitian ini, maka penulis menggunakan beberapa instrumen penelitian adalah:

\section{Angket (Kuesioner)}

Untuk mendapatkan data, maka penulis menyebarkan angket kepada seluruh sampel untuk diisi yang kemudian hasilnya di analisis. Penulis menyebarkan angket karena dalam penelitian ini, penulis ingin memperoleh data mengenai persepsi siswa tentang manfaat sekolah dan hubungannya dengan minat belajar siswa. Hasil penelitian hubungan antara persepsi tentang manfaat sekolah dengan minat belajar pada siswa kelas X SMK Abdi Negara Binjai. Hasil penelitian dilakukan menggunakan SPSS Version 20.0.

\section{HASIL DAN PEMBAHASAN}

Dari hasil penelitian yang didapat subjek yang berjenis perempuan yang berjumlah 23 dan laki-laki 26 siswa. Berdasarkan hasil deskripsi diketahui hubungan antara persepsi tentang manfaat sekolah dengan minat belajar pada siswa kelas X SMK Abdi Negara Binjai adalah $\mathrm{P}>0,016$ yang mana terdapat penelitian hubungan antara persepsi tentang manfaat sekolah dengan minat belajar pada siswa kelas X SMK Abdi Negara Binjai. Penelitian adalah uraian tentang hal-hal yang berkaitan dengan proses kegiatan penelitian. Oleh karena itu isi laporan penelitian bukan hanya langkah-langkah yang telah dilakukan oleh peneliti saja. Hasil penelitian dilakukan untuk menguji hipotesis penelitian yang mana hipotesis penelitian adalah:

Ho: Tidak ada pengaruh yang tinggi/rendah hubungan antara persepsi tentang manfaat sekolah dengan minat belajar pada siswa kelas X SMK Abdi Negara Binjai

Ha: Ada pengaruh yang tinggi/rendah hubungan antara persepsi tentang manfaat sekolah dengan minat belajar pada siswa kelas X SMK Abdi Negara Binjai.

Afni menyatakan bahwa unsur-unsur minat belajar dibangun dari rasa senang perhatian dan kemauan. Peran minat dalam belajar meliputi: 
1)Menciptakan dan menimbulkan konsentrasi atau perhatian dalam belajar

2) Menimbulkan kegembiraan atau perasaan senang dalam belajar

3) Memperkuat ingatan siswa tentang pelajaran yang gtelah diberikan oleh guru

4) Melahirkan sikap belajar yang positif

5) Memperkecil kebosanan siswa dalam belajar.

Slameto mengungkapkan minat adalah kecenderungan yang tetap untuk memperhatikan dan mengenang beberapa kegiatan . kegiatan yang diminati seseorang, diperhatikan terus-menerus yang disertai rasa senang. Minat merupakan sumber motivasi yang mendorong orang untuk melakukan apa yang mereka inginkan bila mereka bebas memilih. Bila mereka melihat bahwa sesuatu akan menguntungkan, mereka merasa berminat.

\section{KESIMPULAN DAN SARAN}

\section{- KESIMPULAN}

Berdasarkan hasil penelitian yang telah dilakukan, maka dapat disimpulkan bahwa terdapat hubungan yang sangat signifikan antara persepsi manfaat sekolah dengan minat belajar, hal ini dibuktikan dengan nilai hasil koefisien korelasi yang menunjukan angka 0,307 dengan nilai sig 0,016 dimana $\mathrm{P}<0,05$. Artinya semakin tinggi persepsi manfaat sekolah, maka semakin baik minat belajar siswa tersebut. Sebaliknya, semakin rendah persepsi manfaat sekolah, maka minat belajar siswa semakin rendah.

\section{- SARAN}

Berdasarkan temuan peneliti
setelah melakukan penelitian dan
menganalisis hasil penelitian, peneliti
mengajukan beberapa saran terhadap
pihak-pihak yang terkait, sebagai berikut:

\section{Bagi Subjek Penelitin}

Bagi siswa siswi SMK Abdi Negara Binjai yang telah memiliki persepsi manfaat sekolah yang tinggi agar dapat meningkatkan lagi minat belajar mereka dan tetap bersemangat dalam menyelesaikan tugas-tugas yang diberikan oleh pendidik.

\section{Kepada Guru-guru SMK Abdi Negara Binjai}

Bagi guru-guru SMK Abdi Negara Binjai agar dapat memberi siswa support yang baik dalam proses pemebelajaran, dengan cara memberikan nasehat, arahan dan perhatian agar dapat meningkatkan minat belajar siswa dan akan menjadikan siswa selalu mahir dalam menyelesaikan masalah yang sedang dihadapi.

\section{Bagi Penelitian Selanjutnya}

Bagi penelitian selanjutnya yang tertarik meneliti tentang hubungan antara persepsi tentang manfaat sekolah dengan minat belajar siswa diharapkan untuk mencari teori yang lebih baik dan baru terhadap kedua variabel penelitian ini, dan diharapkan juga untuk memperhatikan variabel lainnya yang memiliki hubungan yang lebih kuat dengan variabel yang hendak di teliti, serta dapat melakukan uji coba skala dengan jumlah item yang lebih banyak lagi, dengan responden berbeda dan jumlah responden yang lebih banyak 
sehingga tidak banyak item yang gugur, dan berikanlah pengarahan agar subjek mengisi skala yang disediakan sesuai dengan yang mereka alami.

\section{Bagi Guru Bimbingan Dan Konseling}

Penelitian ini kiranya dapat membantu guru khususnya guru BK dalam memeperhatikan tingkat minat belajar siswa. guru BK kiranya berperan aktif agar proses belajar mengajar dapat berjalan dangan baik, jika minat belajar baik atau meningkat maka proses belajar mengajar pun sesuaidengan yang diharapkan.

\section{KEPUSTAKAAN}

Agung Dwi Pangestu DKK, pengaruh minat terhadap hasil belajar metematika siswa SMA NEGERI 1 ULUIWAL kabupaten KOLAKA TIMUR, FKIP UNIVERSITAS HALUOLEO, 2015 , Hlm 25

Arikunto, Suharsimi. 2000. Prosedur Penelitian Jakarta : PT. Rineka Cipta.

Azwar, Saifudin.2003. Metode Penelitian. Yogyakarta: Pustaka Belajar.

Calhoun \& Acocella. 1990. Psikologi tentang Penyesuaian dan hubungan kemanusiaan. Semarang: IKIP Press.

Cholid, Narbuko dan Abu Achmadi.2004. Metodologi Penelitian. Jakarta: PT. Bumi Aksara.

Daryanto S.S. 1997. Kamus Bahasa Indonesia Lengkap. Surabaya: Apollo.

Hurlock Elizabeth. 2002. Psikologi Perkembangan. Jakarta: PT Erlangga.
Jefkins, Frank. 1996. Periklanan. Jakarta: Erlangga.

Jihad, Asep dan Haris, Abdul. 2012.

Evaluasi Pembelajaran. Cet. 1; Yogyakarta: Multi Pressindo. 